\title{
Not hurting students' feelings(Sisu Sitha Noridawa): The impact of a specialized training on teacher mental health literacy in central Sri Lanka
}

P. Ginige ( $\sim$ pabasariginige@gmail.com )

University of Peradeniya https://orcid.org/0000-0002-0114-2890

Perera R.U

University of Peradeniya

Arambepola S.C.

University of Peradeniya

Kuruwita P.R

University of Peradeniya

Gunawardena N.D.

University of Peradeniya

\section{Research Article}

Keywords: mental health literacy, knowledge, attitudes, children, teacher-training

Posted Date: February 9th, 2021

DOI: https://doi.org/10.21203/rs.3.rs-221711/v1

License: (c) (1) This work is licensed under a Creative Commons Attribution 4.0 International License. Read Full License 


\section{Abstract}

Background Globally $10-20 \%$ of children and adolescents are suffering from mental health disorders. Improving mental health literacy $(\mathrm{MHL})$ of teachers supports early detection and referral of children with mental health problems.

Aim To develop and conduct a training program to improve teachers' MHL, "Sisu Sitha Noridawa (SSN)" (not hurting students' feelings) in central Sri Lanka (SL) and to explore the effect of the intervention on teacher MHL.

Method 251 teachers participated in the study. Psychiatrist authors first facilitated small group discussions on ten case vignettes of common child psychiatry problems and then large group discussions using mini lectures and a handbook. Pre and post-tests were conducted to assess knowledge and attitudes on mental health problems of school children. The scores were analyzed using, Paired Ttest in SPSS 17.

Results The mean score differences of pre and posttest in both knowledge and attitude components showed statistically significant differences with $p$ values $<0.001$ (confidence interval of $95 \%$ ) and Cohen's $d$ values $>0.2$ in each, indicating the training had a significant positive impact on improving both the knowledge and attitude about mental health.

Conclusion The training program had a significant positive impact on improving the MHL of participant teachers on common child and adolescent mental health problems. The sustainability of achieved effects and their application in classroom need exploration in a long-term study. SSN is a feasible and effective training program to be included in the existing teacher-training curriculum with in-service booster SSN programs, in a middle-income country like SL.

\section{Introduction}

World Health Organization (WHO) claims about $20 \%$ of children and adolescents will contract an emotional and/or behavioral disorder during their life time ${ }^{1,2}$. They can have a drastic impact on the academics and social life of these children, depriving them from achieving their full potential. ${ }^{3}$ Teachers play an important role in the life of children and adolescents as a group who has the unique opportunity to spend a considerable amount of time with them observing their behaviour, academic performance and social interactions during the most wakeful hours of the day. Especially in rural settings of developing countries, teachers play a significant role in the community as they usually have a fair awareness of the students' family backgrounds and are capable of advising the family in various issues including health related problems ${ }^{4}$. Therefore, it is of paramount importance that the teachers have high mental health literacy (MHL).

MHL is defined as knowledge and beliefs about mental disorders that aid their recognition, management and prevention ${ }^{5}$. Deficiency in MHL of the public can hinder the evidence based mental health care ${ }^{6}$. 
Research conducted worldwide have revealed that there are inadequacies in $\mathrm{MHL}$ of teachers ${ }^{4,7,8}$. In a Brazilian study on public school teachers' perceptions about mental health, $80.6 \%$ have showed great interest in acquiring knowledge; yet the lack of reliable sources of education created lack of confidence in managing everyday situations involving mental health problems ${ }^{9}$. The same study revealed that the television was the source that provides information in the case of $61.3 \%$ of the teachers ${ }^{9}$. The clinician authors of current study come across many children who face adversities in the hands of the teachers due to poor MHL of those teachers.

Studies have shown that the improvement of MHL of the teachers is helpful in early detection of students suffering from mental disorders and aids early referral to professional care ${ }^{10,11}$. School based programs such as Canadian mental health and high school curriculum guide (The Guide) and the African version of the Guide significantly improved knowledge, decreased stigma and enhanced help-seeking efficacy among teachers ${ }^{12,13,14,15}$. In a Tanzanian study more than 200 students with potential mental health issues were identified and referred for professional care following a training program to improve $\mathrm{MHL}^{12}$.

Sri Lankan data shows the prevalence of child and adolescent mental health problems is a considerable health issue in the country. In a national survey, $18.9 \%$ of the adolescents aged $13-18$ years showed some abnormality in emotional and behavioral parameters 16 . Out of them $15.5 \%$ and $12.4 \%$ were severely affected in educational functioning and peer relationships respectively. In central SL, $13.8 \%$ of school children aged 7-11 years showed emotional and behavioral problems ${ }^{17}$.

The concept of MHL is not much familiar in Sri Lankan context. The stigma in relation to mental health is high in the country ${ }^{18}$. This probably contributes to poor conceptualization of MHL in general. There are a few published studies on MHL of various stakeholders in mental health ${ }^{19,20}$. However, there are no published studies in SL on evaluation of MHL of teachers. Teachers learn some child psychology principles briefly at the teacher training schools. There are diploma level courses in early childhood and primary education which include social and personality psychology as sub-courses at the only government run open university ${ }^{21}$. A few non-governmental organizations (NGOs) and individual mental health professionals conduct haphazard training programs for teachers on request of individual schools. There are no regular island wide hands on skills training programs for teachers on emotional and behavioural disorders among children and adolescents.

The clinician authors come across school children and adolescents with mental health problems whose teachers have either failed to detect the problem or managed it adversely, over decades, on a regular basis. That further deteriorates the condition leading to unfortunate circumstances like poor school performance and worsening of the emotional /behavioural problems such as school refusal, withdrawal and irritability. In order to change this on going adversity, a teacher-training program to improve MHL on emotional and behavioural disorders of childhood and adolescents was developed and delivered. The training was named sisu sitha noridawa (SSN) meaning, "not hurting the feelings of the student" in Sinhala, the main language in SL. The phrase was coined based on the famous Sinhala poem guru sitha 
noridawa which means, "Not hurting the feelings of the teachers" in order to catch the attention of a wider audience of teachers for the training. The effectiveness of the intervention (the training) was evaluated statistically.

\section{Methodology}

The necessity of a program to improve MHL of teachers in order to facilitate early detection, appropriate class room management and if necessary, referral of children and adolescents with mental health problems was suggested to the local educational authorities and due approval was obtained from them for the study. The training was conducted at the auditorium of the Teaching Hospital, Kandy, SL in collaboration with local ministries of education and health. A convenient sample of 251 primary teachers from 3 educational zones (namely Kandy, Dewinuwara and Katugasthota) out of the 6 educational zones in Kandy district government schools in Central Province, SL was selected for the study. Three one - day workshops on 3 different days were conducted for each group from each zone. The participants completed a bio data sheet of basic information, namely, participant number, age, sex, civil status, nationality, religion, area of living, level of education, name of the current school, total service duration, number of schools served, records of behavioral and emotional problems of own children and those of children in their classrooms.

A days' group was divided into 10 small groups and 10 case vignettes of common childhood behavioral, emotional and neurodevelopmental problems, namely, oppositional defiant disorder, conduct disorder, attention deficit hyperactivity disorder, autism, dyslexia, mental retardation, depression, separation anxiety disorder, anxiety around sexuality and anxiety around bullying (both by students and teachers advertently or inadvertently) were distributed one vignette per one small group. A comprehensive handbook that was prepared for the training was given to each participant. The handbook contained key identifying features of the conditions discussed in the vignettes and guidelines for classroom management of each case with referral process if necessary. First, the teachers were requested to detect the problems and come up with suggested classroom management plan in small groups without consulting the handbook. Then the 3 psychiatrists in the author panel facilitated an interactive comprehensive discussion in the large group setting on each case vignette with references to the handbook and relevant mini lectures on power point. A certificate of participation was awarded for each participant as an immediate incentive.

The effect of the training program on the MHL was assessed by a pre and post-test through selfadministered written questionnaires on knowledge and attitude in mental health problems in children and adolescents. The questionnaires were prepared based on the clinical experience of the clinician authors and the cultural context. They were in Sinhalese language. The questionnaire of the knowledge component comprised of 35 questions of true-false type while that on attitude comprised of 14 questions with a 5-point Likert scale (Tables 1 and 2 respectively). The pre and posttest results were recorded and analyzed using SPSS 17.0. The paired T test was used to assess whether there was a significant improvement in attitude and knowledge in mental health following the workshop. 


\section{Results}

Out of the 251 teachers that participated for the study 205 (81.67\%) were females and $98.01 \%$ were Buddhists while $1.59 \%$ and $0.04 \%$ belonged to Islam and other religions respectively. The sample consisted of $41.43 \%$ of teachers from Kandy zone whereas $30.28 \%$ and $28.29 \%$ were from Denuwara and Katugastota zones respectively. The participants came from all the different school categories; $1 \mathrm{AB}$ with science, arts and commerce streams for Advanced level (A/L) course (28.69\%), $1 \mathrm{C}$ with no Science for A/L (12.75\%), Type 2 with classes from Grade 1 up to Grade 11 (21.91\%) and Type 3 (primary) schools with classes from grade 1 to 8 or Grade 1 to 5 comprising the largest individual group from one category (36.65\%).

The participant teachers were of a wide variety of educational backgrounds. Most, $48.21 \%$ of the sample was A/L educated. Out of the teachers $33.86 \%, 8.76 \%, 6.37 \%$ and $2.79 \%$ owned a basic degree, diploma, $\mathrm{PhD}$ and MA respectively. 185 (73.71\%) teachers revealed that they have encountered children with emotional and behavioral problems and $12.35 \%$ of the participants had their own children suffering from some mental health issue.

The knowledge questionnaire comprised of 35 questions and 1 mark was awarded per each correct answer. In the pretest of the knowledge component $(n=251)$, the mean score was 26.33 . This significantly improved after the workshop with a posttest mean score of 27.38. (Figure 1) The percentage of accurate responses to most of the components in the knowledge questionnaire was increased following the program. (Table 1) The change of the outcomes is statistically significant with a p value of $<0.001$ (confidence interval of 95\%). The Cohen's $d,(d=0.29)$, exceeded the Cohen's condition for a small effect $(d=0.2)$ indicating that there is a significant difference between the two means.

Out of 251 participants only 236 participants had correctly filled the attitude questionnaire and hence considered for the study. The pretest in attitude component of the participants $(n=236)$ had a mean score of 55.9364. This improved to a mean score of 59.0678 in the posttest (figure 2). The percentage of the most favorable response for each sentence was increased following the program (Table 2). According to the paired T-test, the change of outcomes is statistically significant, the p value being $<0.001$ (confidence interval of $95 \%)$ and the Cohen's $d$ value is $0.4(d>0.2)$. The results indicate that the training program had a significant positive impact on improving both the knowledge and attitude components of teachers on child and adolescent mental health issues.

\section{Discussion}

There is a growing global interest in bringing $\mathrm{MHL}$ into the school setting ${ }^{22,23}$. There are many school friendly interventions that have been carried out to achieve improved school $\mathrm{MHL}^{24.25 .26}$. In the South Asian middle income setting in SL, the concept of MHL is little heard of and only a few published research on $\mathrm{MHL}$ was found ${ }^{19}$. The SSN program was also a venue to introduce the term MHL and 
highlight the importance of having high MHL amongst teachers. This type of an interactive approach helps to alleviate many self-identified yet unanswered questions teachers have, on day-to-day child mental health problems and supports their willingness in enhancing knowledge and ability to manage them better ${ }^{27}$. The SSN training clearly resulted in a significant improvement of both the knowledge and attitudes of teachers on child and adolescent mental health. This improvement can be stated as a direct effect of the intervention due to the design of the study where the pre and posttests are done immediately prior and following the program that makes the non-training factors unlikely. To the best of the knowledge of the authors this study is pioneering in SL in exploring the effect of interactive workshop based training on MHL of teachers.

The SSN training program was well received by the participant teachers who actively participated with enthusiasm and lively interactive discussion despite the fact that stigma on mental health is a barrier in achieving mental health promotion in the country. ${ }^{18}$ Authors believe SSN program contributed towards reducing stigma too as knowledge improves understanding and acceptance of mental health issues ${ }^{28}$. Enhancing teachers' knowledge and decreasing stigma could also have a long term and a persistent positive impact on students ${ }^{11,29}$. It will facilitate to improve the MHL of the students as the teachers will impart their new knowledge and attitudes to the students in day to day class room setting. This will in turn lead to self-identification and help seeking behaviors by students consequently reducing child and adolescent mental health morbidity and mortality $11,30,31$.

There is no organized and regular national teacher-training program to improve $\mathrm{MHL}$ in SL. For an intervention to be successful it should be effective, realistic, feasible and contextually specific ${ }^{32}$. The SSN training program fulfills these requirements and therefore it is a favorable and economically bearable resource that can be implemented in a middle-income, developing country.

The evaluation of results is important in providing information to the clinicians on how to improve the training program. It guides in identifying the areas that the teachers have performed inadequately in knowledge/attitude, posttest and this would be helpful in modifying the training program to address the deficiencies.

Though this study shows outstanding results it was conducted in only 3 educational zones in the Central Province (out of 9 provinces of $S L$ ) and it limits our ability to generalize the effects to the whole country. To overcome this the training could be extended to the other 8 provinces with slightly different geographical, social and cultural settings and evaluated for the effectiveness. The SSN training program can be endorsed as suitable to be embedded in the national teacher training curriculum if the central province results are replicated across the country. The worldwide emphasis is to incorporate training in $\mathrm{MHL}$ into the existing school curriculum structure ${ }^{12,30}$. It has been shown that including mental health literacy into regular curriculum legitimizes the educational value of the material ${ }^{25}$. Moreover, such embedding of the program in the teacher training curriculum rather than conducting it as a separate course or a training program will prevent sensationalizing mental health problems and in turn stigma 
around mental health ${ }^{25}$. Booster training programs of SSN at regular intervals within the teacher training curriculum of training colleges and at in-service trainings will be effective in consolidating the new knowledge and attitudes.

The study measures the immediate results of the intervention and does not guarantee a long-term positive impact or an ability to apply achieved effects into real life classroom problems. A few low income countries have conducted studies in collaboration with resource rich countries like Canada where the teachers are trained in application of mental health literacy resource into their classrooms; the outcomes have been promising ${ }^{22}$. The SSN can be upgraded, as the next step to a didactically familiar classroom based training program to improve both the teachers' and students' $\mathrm{MHL}^{12}$.

\section{Conclusion}

This study was conducted to evaluate the success of the interactive workshop based SSN training program on improving the MHL of teachers. Improving the mental health literacy of teachers will pave the way towards early diagnosis, proper classroom management and referral of the child and adolescent with mental health problems, which is the ultimate goal of this effort. There was a statistically significant improvement in both knowledge and attitude component following the training. "Sisu Sitha Noridawa" (Not hurting the students' feelings) is a favorable training program, which is effective and financially realistic to improve MHL of teachers in the study population. It can be embedded in the teacher training curriculum of Sri Lanka provided the results are replicated in a more representative sample across the country. This study can be improved by adding an arm for evaluation of the sustainability and applicability of the short -term effects achieved from the training. Finally this could be a stepping-stone to an internationally collaborated interventional study to improve teacher MHL that could be used as a model for middle- income country teacher training on MHL.

\section{Declarations}

\section{Conflict of interest statement:}

None of the authors have any conflicts of interest. First author and the $5^{\text {th }}$ author only had access to the study data. The provincial ministry of education sponsored only the training workshop and neither had no involvement with the data collection, analysis and interpretation of data, writing of the report and the decision to submit the paper for publication nor any proprietary or financial interest in the outcome of the study.

\section{The contribution of each author}

1. The conception of the work Ginige P.

2. Design and delivery of the work Ginige P, Perera I.B.R.U and Arambepola S.C.A

3. The acquisition of data and analysis Ginige P, Kuruwita K.A.P.R, Gunawardena E.R.N.D. 
4. Interpretation of data and Drafting the work Ginige P, Kuruwita K.A.P.R, Gunawardena E.R.N.D, Arambepola S.C.A revising it critically for important intellectual content

5. Final approval of the version to be published Ginige $P$ and all other

\section{Acknowledgment}

Dr. Sepali Wickramathilake, consultant community physician MBBS, MD, Ministry of Health, Provincial Council, Central Province, Kandy, Sri Lanka is appreciated for coordinating and organizing ministerial funds for the training program.

\section{Funding}

This research did not receive any specific grant from funding agencies in the public, commercial, or notfor-profit sectors.

\section{Presentation information}

This study was presented as an abstract at the Sri Lanka College of Psychiatrists $14^{\text {th }}$ annual academic sessions, Colombo, Sri Lanka, 27-30 ${ }^{\text {th }}$ April 2017.

\section{Ethics/Consent}

The study was based on a training program we developed and delivered for teachers. We got the approval to conduct the training from the due educational authorities of the Provincial Ministry of Education, Central Province, SL. The teachers participated willingly in response to the request from the ministry. We got their informed consent to compare and contrast the pre and post training knowledge and attitude on mental health.

\section{References}

1. World Health Organization. Child and adolescent mental health. [cited $20^{\text {th }}$ July 2015] Available from: URL: http://www.who.int/mental_health/maternal-child/child_adolescent/en/.

2. Kieling C, Baker-Henningham H, Belfer M, Conti G, Ertem I, Omigbodun O, Rohde LA, Srinath S, Ulkuer N, Rahman A. Child and adolescent mental health worldwide: evidence for action. The Lancet. 2011, 22:378(9801):1515-25.

3. Patel V, Flisher AJ, Hetrick S, McGorry P. Mental health of young people: a global public-health challenge. The Lancet. 2007, 14:369(9569):1302-13.

4. Mendonsa RD, Shihabuddeen I. Mental health literacy among elementary school teachers in Rural South India. Delhi Psychiatry Journal. 2013;16(2):362-5.

5. Jorm AF, Korten AE, Jacomb PA, Christensen H, Rodgers B, Pollitt P. "Mental health literacy": a survey of the public's ability to recognise mental disorders and their beliefs about the effectiveness of treatment. Medical journal of Australia. 1997, 166(4):182-6. 
6. Jorm AF. Mental health literacy: Public knowledge and beliefs about mental disorders. The British Journal of Psychiatry. 2000, 177(5):396-401.

7. Kurumatani T, Ukawa K, Kawaguchi Y, Miyata S, Suzuki M, Ide H, Seki W, Chikamori E, Hwu HG, Liao SC, Edwards GD. Teachers' knowledge, beliefs and attitudes concerning schizophrenia. Social Psychiatry and Psychiatric Epidemiology. 2004, 1:39(5):402-9.

8. Masillo A, Monducci E, Pucci D, Telesforo L, Battaglia C, Carlotto A, Forte A, Bonaccorsi E, Romano A, Fiori Nastro P, Girardi P. Evaluation of secondary school teachers' knowledge about psychosis: a contribution to early detection. Early intervention in psychiatry. 2012, 6(1):76-82.

9. Soares AG, Estanislau G, Brietzke E, Lefèvre F, Bressan RA. Public school teachers' perceptions about mental health. Revista de saude publica. 2014, 48:940-8.

10. Fazel M, Hoagwood K, Stephan S, Ford T. Mental health interventions in schools in high-income countries. The Lancet Psychiatry. 2014, 1;1(5):377-87.

11. Kutcher S, Gilberds H, Morgan C, Udedi M, Perkins K. Malawi educators' assessment of student mental health outcomes. Int J Sch Cog Psychol S. 2015, 2:009.

12. Kutcher S, Wei Y, Gilberds H, Ubuguyu O, Njau T, Brown A, Sabuni N, Magimba A, Perkins K. A school mental health literacy curriculum resource training approach: effects on Tanzanian teachers' mental health knowledge, stigma and help-seeking efficacy. International Journal of Mental Health Systems. 2016, 10(1):1-9.

13. Kutcher S, Wei Y, Morgan C. Successful application of a Canadian mental health curriculum resource by usual classroom teachers in significantly and sustainably improving student mental health literacy. The Canadian Journal of Psychiatry. 2015, 60(12):580-6.

14. Kutcher S, Wei Y, Gilberds H, Brown A, Ubuguyu O, Njau T, Sabuni N, Magimba A, Perkins K. The African Guide: One Year Impact and Outcomes from the Implementation of a School Mental Health Literacy Curriculum Resource in Tanzania. Journal of Education and Training Studies. 2017, 5(4):6473.

15. org (2014b). School Mental Health - The Curriculum Guide. [cited 24.8.2017]. Available from: URL: http://teenmentalhealth.org/curriculum

16. Perera H. Mental health of adolescent school children in Sri Lanka-a national survey. Sri Lanka Journal of Child Health. 2004, 33(3):78-81.

17. Ginige P, Tennakoon SU, Wijesinghe WH, Liyanage L, Herath PS, Bandara K. Prevalence of behavioral and emotional problems among seven to eleven year old children in selected schools in Kandy District, Sri Lanka. Journal of affective disorders. 2014, 1;167:167-70.

18. Samarasekara N, Davies ML, Siribaddana S. The stigma of mental illness in Sri Lanka: the perspectives of community mental health workers. Stigma Research and Action. 2012, 31;2(2).

19. Attygalle UR, Perera $H$, Jayamanne BD. Mental health literacy in adolescents: ability to recognise problems, helpful interventions and outcomes. Child and adolescent psychiatry and mental health. 2017, 11(1):1-8. 
20. Ediriweera HW, Fernando SM, Pai NB. Mental health literacy survey among Sri Lankan carers of patients with schizophrenia and depression. Asian journal of Psychiatry. 2012, 1;5(3):246-50.

21. Open University of Sri Lanka. Diploma in Early Childhood \& Primary Education Program. 2016/2017. [cited 22.8.2017] Available From: URL:

http://www.ou.ac.lk/home/images/Programmes/FurtherInformation/DECPE-Brochure-2016-2017E.pdf.

22. Kutcher S, Gilberds H, Morgan C, Greene R, Hamwaka K, Perkins K. Improving Malawian teachers' mental health knowledge and attitudes: an integrated school mental health literacy approach. Global Mental Health. 2015;2.

23. Rowling L, Weist M. Promoting the growth, improvement and sustainability of school mental health programs worldwide. International Journal of Mental Health Promotion. 2004, 1;6(2):3-11.

24. Perry Y, Petrie K, Buckley H, Cavanagh L, Clarke D, Winslade M, Hadzi-Pavlovic D, Manicavasagar V, Christensen $\mathrm{H}$. Effects of a classroom-based educational resource on adolescent mental health literacy: A cluster randomised controlled trial. Journal of adolescence. 2014, 1;37(7):1143-51.

25. Mcluckie A, Kutcher S, Wei Y, Weaver C. Sustained improvements in students' mental health literacy with use of a mental health curriculum in Canadian schools. BMC psychiatry. 2014,14(1):1-6.

26. Skre I, Friborg O, Breivik C, Johnsen LI, Arnesen Y, Wang CE. A school intervention for mental health literacy in adolescents: effects of a non-randomized cluster controlled trial. BMC Public Health. 2013,13(1):1-5.

27. Forese-Germain B, Riel R. Understanding Teachers' Perspectives on Student Mental Health. [cited 24.08.2017] Available from: URL: https://www.ctf-fce.ca/ResearchLibrary/StudentMentalHealthReport.pdf.

28. Gaiha SM, Sunil GA, Kumar R, Menon S. Enhancing mental health literacy in India to reduce stigma: the fountainhead to improve help-seeking behaviour. Journal of Public Mental Health. 2014, 9:13(1):146-58.

29. Daniszewski TD. Teachers' Mental Health Literacy and Capacity towards Student Mental Health. Electronic Thesis and Dissertation Repository. [cited 9.9.2017]. Available from: URL: http://ir.lib.uwo.ca/etd/1165.

30. Kelly CM, Jorm AF, Wright A. Improving mental health literacy as a strategy to facilitate early intervention for mental disorders. Medical Journal of Australia. 2007, Suppl 7: 26-30.

31. Kutcher, S., Bagnell, A., \& Wei, Y. (2015). Mental health literacy in secondary schools: a Canadian approach. Child and Adolescent Psychiatric Clinics, 24(2), 233-244.

32. Kutcher S, Bagnell A, Wei Y. Mental health literacy in secondary schools: a Canadian approach. Child and Adolescent Psychiatric Clinics. 2015, 1;24(2):233-244.

33. Kutcher S, Wei Y, McLuckie A, Bullock L. Educator mental health literacy: a programme evaluation of the teacher training education on the mental health $\&$ high school curriculum guide. Advances in school mental health promotion. 2013, 1;6(2):83-93. 
Koonin EV, Altschul SF, Bork P: BRCA1 protein products: functional motifs. Nat Genet 1996, 13:266-267.

Koonin EV, Altschul SF, Bork P. ... Functional motifs.... Nature genetics. 1996 Jul;13(3):266-8.

\section{Tables}

Table 1: Knowledge questionnaire and the percentage of accurate responses of the pre and post tests 
Knowledge Questionnaire

$\begin{array}{lll}\text { Yes/No } & \text { Pre } & \text { Post } \\ & \text { Test } & \text { test }\end{array}$

1. Only adults have mental health disorders.

No

247

245

$98.4 \%$

$97.6 \%$

2. Children and adolescent brains are not developed enough to have mental health problems.

$\begin{array}{lll}220 & 236 \\ \text { No } & & \\ & 87.6 \% & 94 \%\end{array}$

3. Medication is the only answer in most of the emotional and behavioral disorders in children.

No

$96.8 \%$

4. Mental health problems do not affect behavior of the students.

No

231

231

$92 \%$ 92

5. Mental health problems do not affect performance of the students

227

222

$88.4 \%$

6. Children with anxiety disorders may panic in situation that they fear

193

Yes $\quad 76.9 \% \quad 208$

$82.9 \%$

7. Children with phobias can be helped by making them relaxed and feel supported.

241

239

8. A child who does not speak at school all the time, but speak well at
home may be doing so due to defiance.

Yes

$96 \%$

$95.2 \%$

209

201

9. Depression is sadness

No

$83.3 \%$

$80.1 \%$

9. Depression is sadness

135

111

10. Only weak-minded children develop depression.

No

$53.8 \%$

$44.2 \%$

No

210

206

$83.7 \%$

$82.1 \%$

11. Common symptoms of childhood depression are getting angry and disobedient

168

Yes
$66.9 \% \quad 198$ 
12. Childhood depression may cause poor school performance and school refusal

Yes $\quad 89.2 \% \quad 94.4 \%$

13. Children with Attention Deficit Hyperactivity Disorder

$147 \quad 141$

(ADHD) can concentrate on their work at least for 20 minutes

No

$58.6 \%$

$56.2 \%$

14. Children with ADHD are more impulsive, disorganized and forgetful.

$181 \quad 192$

15. A reasonable punishment can cure ADHD.

$72.1 \% \quad 76.5 \%$

Yes

182

161

No

$72.5 \%$

$64.1 \%$

16. Difficulty in reading, writing and doing mathematics are not mental health problems.

\begin{tabular}{lll} 
& 102 & 119 \\
No & $40.6 \%$ & $47.4 \%$ \\
& 223 & 219 \\
Yes & $88.8 \%$ & $87.3 \%$ \\
\hline & 228 & 231
\end{tabular}
17. Students with specific learning disorders may have normal or
superior intelligence.

18. If a child shows less intelligence there is nothing a mental health professional can do about that child.

19. Children with Mental Retardation (MR) appear to forget what is taught.

No $\quad 90.8 \% \quad 92 \%$

20. Children with MR are poor in all performances at school.

$200 \quad 195$

20. Children with $M$ R are poor in all performances at school.

Yes $\quad 79.7 \%$

$77.7 \%$

$217 \quad 218$

21. Children with Autism have poor social interactions.

No

$86.5 \%$

$86.9 \%$ 22. Children with Autism could be highly intelligent or have low
Intelligence.

23. Children with autism develop psychosis later.

$134 \quad 167$

Yes

$53.4 \%$

$66.5 \%$

176203

Yes

$70.1 \%$

$80.9 \%$

24. Children with Oppositional Defiant Disorder (ODD) have a less severe condition than children with Conduct Disorder (CD).

175209

No

$69.7 \%$

$83.3 \%$

$\begin{array}{lll} & 131 & 170 \\ \text { Yes } & 52.2 \% & 67.7 \%\end{array}$

25. Children with ODD and CD often bully, threaten or intimidate 175 203 others.

$\begin{array}{lll} & 175 & 203 \\ \text { Yes } & 69.7 \% & 80.9 \%\end{array}$


26. Children with ODD and CD deliberately annoy others.

\begin{tabular}{|c|c|c|c|}
\hline & Yes & $65.7 \%$ & $85.7 \%$ \\
\hline \multirow[t]{2}{*}{ 27. Children with ODD and CD may not be angry and resentful. } & \multirow[t]{2}{*}{ No } & 39 & 30 \\
\hline & & $15.5 \%$ & $12 \%$ \\
\hline \multirow[t]{2}{*}{ 28. Unknown people sexually abuse children, mainly. } & \multirow[t]{2}{*}{ No } & 153 & 148 \\
\hline & & $61 \%$ & $59 \%$ \\
\hline \multirow{2}{*}{$\begin{array}{l}\text { 29. Sexually abused children often feel guilty thinking they were } \\
\text { abused because they were at fault. }\end{array}$} & & 151 & 173 \\
\hline & Yes & $60.2 \%$ & $68.9 \%$ \\
\hline \multirow{2}{*}{$\begin{array}{l}\text { 30. Alcohol and other substances of abuse have less addictive effect } \\
\text { in developing brain. }\end{array}$} & \multirow[t]{2}{*}{ No } & 111 & 114 \\
\hline & & $44.2 \%$ & $45.4 \%$ \\
\hline \multirow{2}{*}{$\begin{array}{l}\text { 31. Having a balanced diet and adequate sleep improve mental health } \\
\text { well-being of students. }\end{array}$} & \multirow[t]{2}{*}{ Yes } & 228 & 221 \\
\hline & & $90.8 \%$ & $88 \%$ \\
\hline \multirow[t]{2}{*}{ 32. Giving praise improve mental health well-being of students. } & \multirow[t]{2}{*}{ Yes } & 241 & 240 \\
\hline & & $96 \%$ & $95.6 \%$ \\
\hline \multirow{2}{*}{$\begin{array}{l}\text { 33. Talking over problems with students helps to build better mental } \\
\text { health }\end{array}$} & & 234 & 243 \\
\hline & Yes & $93.2 \%$ & $96.81 \%$ \\
\hline \multirow{3}{*}{$\begin{array}{l}\text { 34. Physical exercise helps to improve the mental health well - being of } \\
\text { students. }\end{array}$} & \multirow{3}{*}{ Yes } & 232 & 236 \\
\hline & & & $94 \%$ \\
\hline & & $92.4 \%$ & \\
\hline \multirow{2}{*}{$\begin{array}{l}\text { 35. Having a positive relationship with students and doing something } \\
\text { students enjoy improve mental health well- being of both teachers and } \\
\text { students }\end{array}$} & \multirow[b]{2}{*}{ Yes } & 242 & 242 \\
\hline & & & $96.4 \%$ \\
\hline
\end{tabular}

Table 2: Attitude questionnaire and percentages of favorable responses of the pre and posttests 


\begin{tabular}{|c|c|c|c|}
\hline Attitude Component & $\begin{array}{l}\text { Likert } \\
\text { scale } \\
\text { statement }\end{array}$ & $\begin{array}{l}\text { Pre- } \\
\text { test }\end{array}$ & $\begin{array}{l}\text { Post - } \\
\text { test }\end{array}$ \\
\hline \multirow[t]{2}{*}{ 1. Having high mental health literacy makes life easy as a teacher } & \multirow{2}{*}{$\begin{array}{l}\text { Totally } \\
\text { Agree }\end{array}$} & 176 & 210 \\
\hline & & $70.1 \%$ & $83.7 \%$ \\
\hline \multirow[t]{2}{*}{ 2.Having a mental illness ruins one's life } & \multirow{2}{*}{$\begin{array}{l}\text { Totally } \\
\text { Disagree }\end{array}$} & 45 & 97 \\
\hline & & $17.9 \%$ & $38.6 \%$ \\
\hline \multirow[t]{2}{*}{ 3.People with mental illnesses are never getting better } & \multirow{2}{*}{$\begin{array}{l}\text { Totally } \\
\text { Disagree }\end{array}$} & 162 & 193 \\
\hline & & $64.5 \%$ & $76.3 \%$ \\
\hline \multirow[t]{2}{*}{ 4.Seeking help for mental illness is a sign of weakness } & \multirow{2}{*}{$\begin{array}{l}\text { Totally } \\
\text { Disagree }\end{array}$} & 195 & 208 \\
\hline & & $77.7 \%$ & $82.9 \%$ \\
\hline \multirow{2}{*}{$\begin{array}{l}\text { 5.Seeking help for mental illness is not good for the record of a } \\
\text { child's future }\end{array}$} & \multirow{2}{*}{$\begin{array}{l}\text { Totally } \\
\text { Disagree }\end{array}$} & 159 & 182 \\
\hline & & $63.3 \%$ & $72.5 \%$ \\
\hline \multirow{2}{*}{$\begin{array}{l}\text { 6.Mental illnesses are caused by a personal weakness or character } \\
\text { flow }\end{array}$} & \multirow{2}{*}{$\begin{array}{l}\text { Totally } \\
\text { Disagree }\end{array}$} & 99 & 111 \\
\hline & & $39.4 \%$ & $44.2 \%$ \\
\hline \multirow{2}{*}{$\begin{array}{l}\text { 7. Role of the special education teacher is less important than that of } \\
\text { a science /math teacher in a school. }\end{array}$} & \multirow{2}{*}{$\begin{array}{l}\text { Totally } \\
\text { Disagree }\end{array}$} & 202 & 216 \\
\hline & & $39.4 \%$ & $86.1 \%$ \\
\hline \multirow{2}{*}{$\begin{array}{l}\text { 8. Role of the Counseling teacher is less important than that of a } \\
\text { science /math teacher in a school }\end{array}$} & \multirow{2}{*}{$\begin{array}{l}\text { Totally } \\
\text { Disagree }\end{array}$} & 197 & 224 \\
\hline & & $80.5 \%$ & $89.2 \%$ \\
\hline \multirow[t]{2}{*}{ 9.Children with mental illness should not be sent to school } & \multirow{2}{*}{$\begin{array}{l}\text { Totally } \\
\text { Disagree }\end{array}$} & 218 & 224 \\
\hline & & $86.9 \%$ & $89.2 \%$ \\
\hline \multirow[t]{2}{*}{ 10.Children with mental illness are dangerous } & \multirow{2}{*}{$\begin{array}{l}\text { Totally } \\
\text { Disagree }\end{array}$} & 149 & 159 \\
\hline & & $59.4 \%$ & $63.3 \%$ \\
\hline \multirow[t]{2}{*}{ 11. Media gives a reasonable idea about mental health problems } & \multirow{2}{*}{$\begin{array}{l}\text { Totally } \\
\text { Disagree }\end{array}$} & 82 & 106 \\
\hline & & $32.7 \%$ & $42.2 \%$ \\
\hline \multirow[t]{2}{*}{ 12. Homosexual orientation is a mental health disorder } & \multirow{2}{*}{$\begin{array}{l}\text { Totally } \\
\text { Disagree }\end{array}$} & 96 & 133 \\
\hline & & $38.2 \%$ & $53 \%$ \\
\hline \multirow{2}{*}{$\begin{array}{l}\text { 13.A female child behaving and thinking like a male child is a } \\
\text { disgrace to a girls school }\end{array}$} & \multirow{2}{*}{$\begin{array}{l}\text { Totally } \\
\text { Disagree }\end{array}$} & 162 & 186 \\
\hline & & $64.5 \%$ & $74 \%$ \\
\hline $\begin{array}{l}\text { 14.It is ok to criticize children to correct them as opposed to } \\
\text { criticizing adults as adults get hurt and fall out with us }\end{array}$ & $\begin{array}{l}\text { Totally } \\
\text { Disagree }\end{array}$ & 161 & 194 \\
\hline
\end{tabular}




\section{Figures}

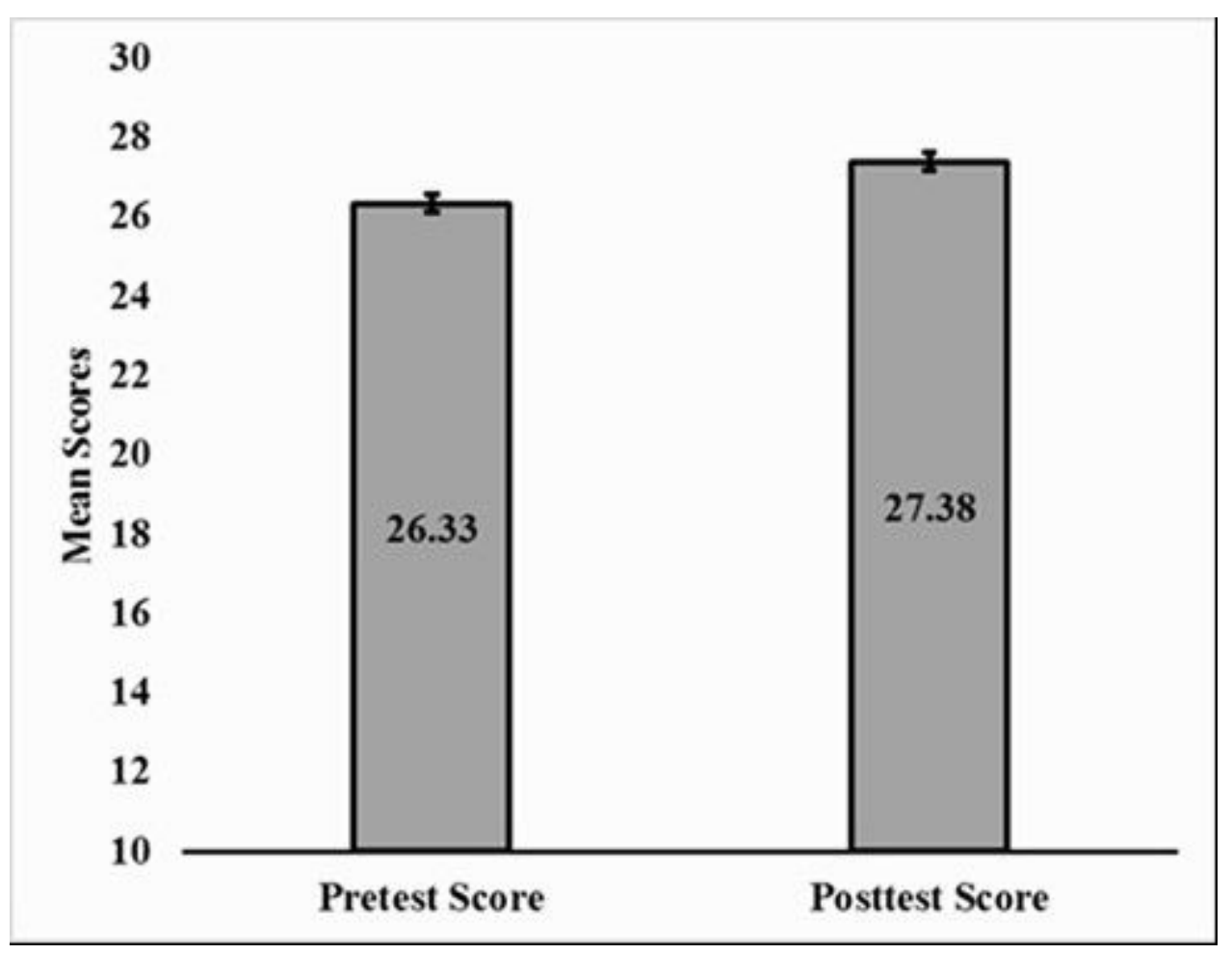

Figure 1

Mean scores of pre and post knowledge tests

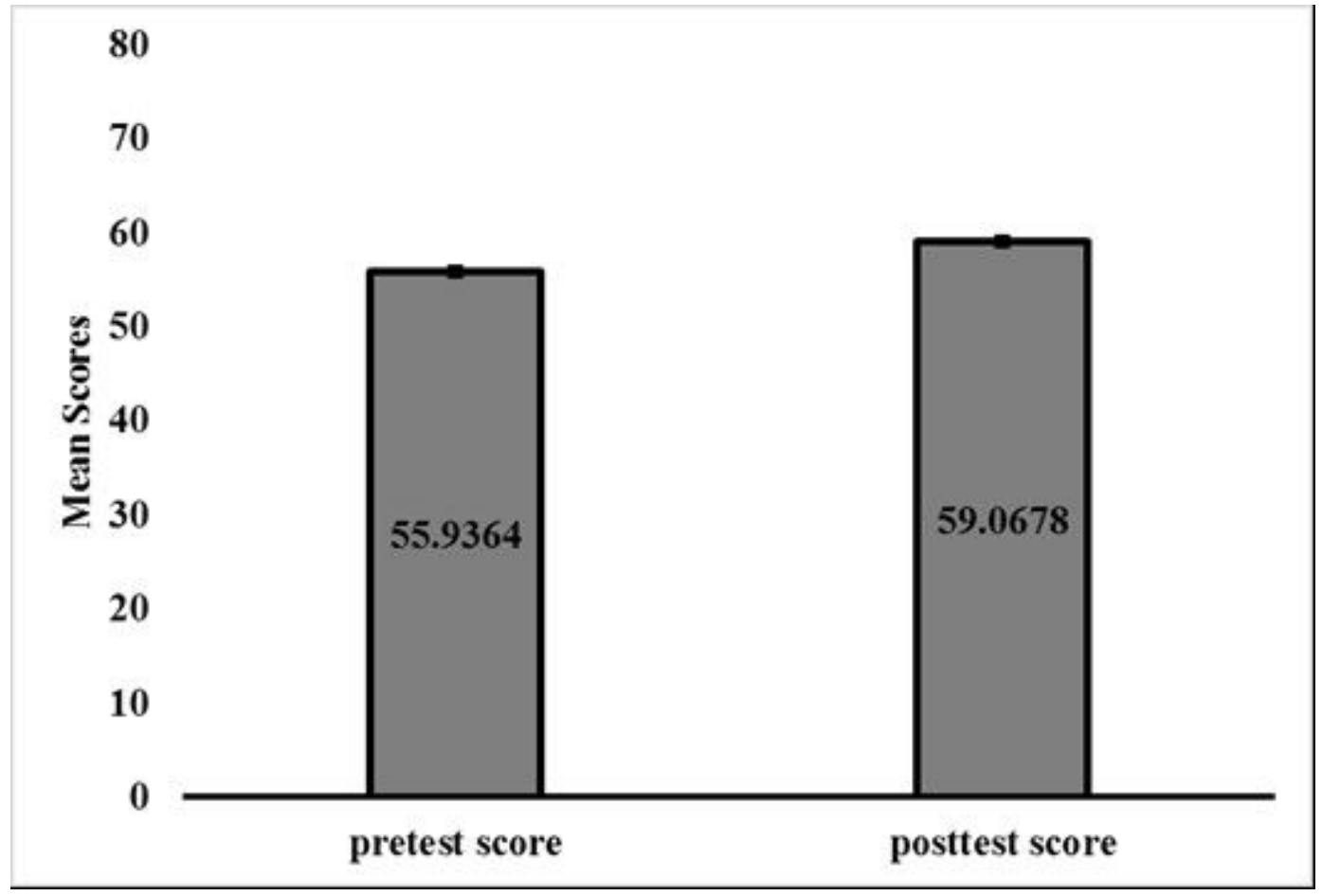

Figure 2 
Mean scores of pre and posttest attitude tests

Page $17 / 17$ 